\title{
Prestige From the Bottom Up: A Review of Language Planning in Guernsey
}

\author{
Julia Sallabank \\ Department of Linguistics and English Language, Lancaster University, Lancaster \\ LA7 4YT, United Kingdom
}

\begin{abstract}
This paper discusses language planning measures in Guernsey, Channel Islands. The indigenous language is spoken fluently by only $2 \%$ of the population, and is at level 7 on Fishman's 8-point scale of endangerment. It has no official status and low social prestige, and language planning has little official support or funding. Political autonomy has not increased the language's status or stopped intergenerational transmission from declining. Most language planning initiatives are very small-scale and are undertaken by pressure groups or individuals, who focus on social prestige at grass-roots level rather than official status. The likelihood of success of current efforts is evaluated.
\end{abstract}

Keywords: endangered languages, revitalisation, status, prestige, planning, attitudes.

\section{Background}

The Channel Islands are in the Gulf of St Malo off the coast of northern France (see Figure 1). Politically the islands are semi-autonomous dependencies of the British Crown, and are self-governing in domestic policy. They are not part of the United Kingdom and are only associate members of the European Community, so they are not subject to European laws or agreements such as the Charter for Regional or Minority Languages. Guernsey is the second largest of the islands, nine miles by seven by five miles ( $14.5 \mathrm{~km}$ by $11 \mathrm{~km}$ by $8 \mathrm{~km})$.

The indigenous language variety in Guernsey has traditionally had very low prestige, and has no official standing. It is now at around level 7 on Fishman's (1991) 8-point scale of language endangerment, that is, most native speakers are past child-bearing age. According to the 2001 census, which was the first to ask a language question, $14 \%$ of the total population of nearly 60,000 (i.e. 1 in 7 ) report having some understanding, but only $2 \%$ claim to speak it fluently (the same percentage as Gaelic in Scotland).

The lack of official standing is illustrated by the fact that the variety has no official name. It is often called 'the patois', especially by non-speakers and by those who are not aware of the negative connotations of this word in French, ${ }^{1}$ but this is now objected to by some language campaigners. The census used the term Guernsey Norman French to avoid ambiguity, but this term is not in common use. It is also known as Guernsey French, but the majority of native speakers I have interviewed prefer to call it Guernesiais, so that is the term used in this paper. 


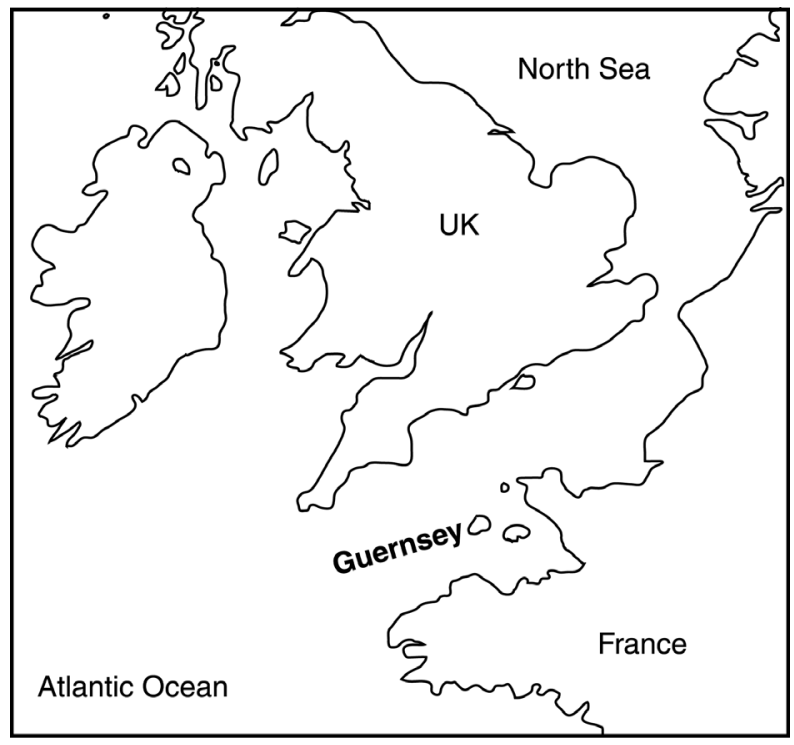

Figure 1 The location of Guernsey in relation to France and the United Kingdom

\section{History}

English is a relatively recent newcomer to Guernsey; in the 18th century Methodist missionaries found very few people who could understand English (Marquis, 1997).

Norman French has been spoken in the Channel Islands for over 1000 years. In 1066 Normandy (of which Guernsey was part) invaded England, and Norman French became the language of the elite in England. The Normans made widespread conquests and Norman became an international language of culture and politics in England, France and Italy, with a large body of literature. At that time the dialect of the Paris area, which later became the favoured variety of the French monarchy and Republic, was a minor local dialect. Norman is nowadays seen as a low-status unwritten patois, and there is relatively little awareness of its prestigious past, although older Guernsey people are proud that their forebears were on the winning side in the Battle of Hastings.

King John of England, a descendant of the Norman conquerors and therefore ruler of both England and Normandy, lost control of mainland Normandy to the French in 1204. However, the Channel Islands chose to remain allied to the English crown; they owe their allegiance directly to the crown rather than to the British Government. In 2004 they celebrated their 800th anniversary of independence.

The loss of mainland Normandy led the Normans in England to adopt a separate, English identity, and eventually the English language, although Norman French remained important until the 15th century, especially in legal documents, and had a profound influence on the development of the English language (Milroy, 1984; Thomason \& Kaufman, 1988). Throughout the mediaeval period the French raided the Channel Islands (Marr, 2001); strategic importance may 
have encouraged the islanders to identify with the English Crown and distance themselves from a French identity.

In the 17th century, Protestant refugees fled to Guernsey from religious persecution in France. At that time Guernsey was ruled by a strict Puritan 'theocracy' (which almost wiped out traditional songs and dances), which welcomed Calvinist preachers fluent in French. According to De Garis (1973: 260 and p.c.), Standard French speakers thus gained positions of influence and introduced negative attitudes towards the indigenous vernacular. French was the High variety until the early 20th century (used for religion, education, government), and as in France it was seen as the language of civilisation. Until the mid 20th century a large proportion of the population was trilingual in Guernesiais, Standard French and English.

In the 19th century, the Napoleonic wars brought an influx of British troops and cut the islands off from France. The development of regular steamboat services facilitated links with the UK, the growth of the tourist industry and increased immigration. The two ports (St Peter Port and St Sampson) became almost completely Anglicised. In 1898 the States (parliament) resolved that English should be permitted in debates, following pressure from St Peter Port members who could not understand French. In 1926, English was adopted as a second official language (Johnstone, 1994).

From 1940 to 1945 the Channel Islands were occupied by the Germans. During the occupation Guernesiais was used more among the islanders who stayed, as a language of solidarity and secrecy. Nearly half of the population was evacuated to the UK just before the invasion, including practically all the children. The break in intergenerational transmission caused by the evacuation is commonly seen as the final nail in the coffin of Guernesiais. Its influence on language use and attitudes is debated: some speakers point out that they or relatives can still speak Guernesiais fluently after longer periods away; but the evacuees had no idea when or if they would return, and Britain in 1940 was intensely paranoid and suspicious of strangers speaking an incomprehensible language with so many / $\mathrm{t} /$ / sounds, so evacuees felt under strong pressure to assimilate. The evacuees were also exposed to a literally less insular worldview, and when they returned were felt by others to 'give themselves airs'. Some non-evacuees also objected to their 'Anglicised twang' when they spoke Guernesiais. Numerous informants have recounted how mistakes were not tolerated among children deemed to be native speakers, so confidence and motivation to speak Guernesiais were undermined. The evacuation probably hastened a process which was already well under way, as language shift is such a common phenomenon. The neighbouring island of Jersey was also occupied, but a much smaller proportion of the population was evacuated (Bunting, 1995); yet Jersey Norman French (Jèrriais) is now similarly endangered.

After the war the prestige of Guernesiais was at its lowest ebb. In the culture of modernity of the time, Guernesiais was increasingly seen as an old-fashioned peasant dialect which would hold people back. English was used for all modern topics, and Guernesiais did not develop terms for new concepts such as refrigerators and bathrooms (Harry Tomlinson, p.c.). Guernsey benefited from UK economic aid, which, however, led to reliance on British expertise; and British teachers told children to 'go home and come back when you can speak English'. 
Tourism increased, bringing yet more English speakers; advertising proudly boasted that the island had no language problem. The advent of mass media brought English into the home, and influenced aspirations and lifestyle.

The banking industry grew rapidly in the 1970s, altering the balance of the previously farm-based economy. Agriculture and horticulture were hit by Britain's entry into the EEC, as well as by the fuel crisis and the British dock strike in the 1970s. Of 2000 tomato and flower growers in 1947, only three firms remain, and 25 farmers out of 425 (Peter J. Falla, interview). The economy is currently booming due to Guernsey's status as a tax haven and offshore banking centre. There is full employment and a high standard of living.

\section{Research Methods}

I have been researching the linguistic situation in Guernsey since early 2000. The research instruments have been:

- a questionnaire intended to discover the extent and contexts of the current use of Guernesiais;

- a questionnaire on attitudes;

- semi-structured and ethnographic interviews; and

- participant observation at language festivals.

Forty residents of Guernsey were interviewed in September 2001. The questionnaire contained a mixture of closed and open questions to facilitate analysis of baseline data. About a third of the interviews were conducted in Guernesiais, ${ }^{2}$ and the recordings include cultural information as well as rhymes and poems which could enrich archive material.

Youngman (1978: 28) suggests that identifying respondents individually has advantages over chance or random mailings, as those who answer these will be self-selected and may be unrepresentative. I therefore identified informants via social networks (Milroy, 1987), but found that this can also have disadvantages. My primary contacts tended to be committed language activists with atypical patterns of use; I was also directed towards 'good speakers' (a problem identified by Watson, 1989:56). Social network contacts are by definition socially integrated, which might skew the picture of the pattern of use if these speakers only were surveyed. In order to contact a wider range of respondents I appealed through the newsletters of local-interest societies such as La Société Guernesiaise (see 'Language revitalisation groups', below) and the Guernsey Society (originally a society for Second World War expatriates) and also took advantage of a generous offer by the then President of La Société Guernesiaise to circulate the questionnaire free of charge with their newsletter. Ninety responses were received, half from speakers of Guernesiais and half from Anglophones. The postal respondents proved to have much less dense social networks in Guernesiais, and lower levels of use.

In May 2004 I circulated another questionnaire aimed at Anglophones to gauge attitudes towards revitalisation of Guernesiais. This questionnaire was distributed via contacts (of whom I by then had a wider variety) and elicited 200 responses, a cross-section of whom were interviewed in depth. Leading politicians and civil servants were also interviewed. A preliminary overview of results 
indicates that the prestige of Guernesiais may be rising, and that there is broad (though qualified) support for revitalisation.

Haarmann (1990: 124) warns that 'observers must always distinguish their interest in sociolinguistics from subjective evaluations of planning activities', and goes on to say that 'such a conflict of interest is a mere academic one and does not involve the conditions of languages and their speakers'. However, in a small community the very fact of having an outside expert doing research into a minority language can raise its prestige, and also encourage discussion of policy issues.

\section{Levels of Use}

Language shift in Guernsey is further advanced than is the case with indigenous minority languages in many European countries. A colleague who visited Guernsey in July 2004 commented that 'If it hadn't been for the place names, the tourist visitor could easily believe the place is monolingually English'. All Guernesiais speakers are bilingual in English and most are elderly; there are relatively few second language learners due to negative attitudes and lack of provision.

As noted in the Census report, there are considerably more people who understand Guernesiais than speak it fluently. Conversations where one interlocutor speaks Guernesiais and the other replies in English are not uncommon, but this requires persistence on the part of the Guernesiais speaker. Campaigners berate the failure to transform passive understanding (or competence, in language acquisition terminology, e.g. Scovel, 1998: 47) into active use (performance), but to do so would need careful encouragement and support. Children in the late 1940s and 1950s needed to understand older monolinguals, but were encouraged by parents to speak only English to improve their chances at school. The lack of Guernesiais-speaking interlocutors contributes to attrition processes in individuals and to the lexical impoverishment of Guernesiais.

My 2001 survey revealed a wide range of levels of use of Guernesiais, from isolated speakers to a community of at least 100 people in early retirement who use Guernesiais for their entire social life (e.g. whist drives, bowls). However, only a small proportion have passed Guernesiais on to their children, and several seem content to let it die with them; others express regret but powerlessness.

Guernesiais is predominantly used in the domestic domain. Respondents reported speaking it most often when meeting friends, at folk festivals, and at home. Festivals and church (mostly speaking to friends before and after services, although some ecumenical services are now held in Guernesiais) provide virtually the only public forums for using Guernesiais (see 'Prestige and image planning', below).

The concept of domain proved difficult to explain to research participants. When asked what sort of things they talked about in Guernesiais, 32\% of postal respondents and $57 \%$ of interviewees replied 'general' or 'anything'. It appears that the deciding factor is not so much domain (as proposed by Fishman, 1991) as type of speech event. English is used for utilitarian events such as commercial and official transactions. Guernesiais fulfils a more phatic or affective role, for socially integrated speakers at least. There is a reluctance to speak Guernesiais with those who may have difficulty in responding comfortably; the circle of 
active speakers thus shrinks progressively. When Guernesiais speakers marry non-speakers, English tends to become the family language to avoid a situation where one parent feels left out of the conversation. Gal (1979) explains this as language choice by interlocutor, but it can also be explained by lack of confidence in Guernesiais due to its low social prestige: speakers are not assertive enough to demand its use. It is not thought polite to speak Guernesiais in front of people who cannot understand what is being said: one respondent commented 'only the Welsh do this'.

It can thus be seen that the prestige of Guernesiais is low, even compared to other European minority languages which have achieved a measure of normalisation and official standing. Supporters of Guernesiais are not uncommonly put in the position of having to defend its value and right to exist, which some understandably resent (De Garis, 1973).

\section{Language Planning in Guernsey}

Fishman (1991) prefaces his 8-point scale of language endangerment with an important caveat for language planners involved in language revitalisation: 'assuming prior ideological clarification' of the relationship between language and culture, what exactly are planners trying to save, and why? Ten years later, Fishman (2001: 541) admits that it is quite common for enthusiasts to embark on revitalisation activities without such clarification, and without convincing arguments with which to counter critics. This is the case in Guernsey, where individuals and groups often disagree on matters such as the desirability of corpus planning, the effectiveness of particular activities, or the linguistic status of Guernesiais. However, a coordinating committee presents a unified face in order to maximise the impact of efforts (see 'Language revitalisation groups', below).

The policy of the authorities, if policy it can be called, has traditionally been one of laissez-faire or benign neglect. Few Guernsey residents, even language enthusiasts, are willing to attribute anti-vernacular motives to this neglect, but it has undoubtedly increased the hegemony of English and had a negative effect on the prestige of Guernesiais. But as noted by Williams (2000: 169), 'the absence of a legal status does not mean that language planning does not exist'.

Language planning is traditionally categorised into four areas, although it is acknowledged that in practice they cannot be implemented without overlap:

- Status planning;

- Corpus planning;

- Language-in-education (or acquisition) planning; and

- Prestige planning. (Kaplan \& Baldauf, 2003: 202)

The term 'prestige planning' was coined by Haarmann $(1984,1990)$ to differentiate activities aimed at promoting a positive view of a language from those concerned with political status or functions: 'not only the content of planning activities is important but also the acceptance or rejection of planning efforts' (Haarmann, 1990: 105).

Ager, in this issue, introduces a new distinction between prestige planning and image planning, namely, increasing confidence in and goodwill towards a language (as in Gardner, 1993). Image planning thus covers many of the areas 
formerly subsumed under prestige planning. Ager claims that prestige planning necessarily involves conflict, but language planning activists in Guernsey prefer to avoid conflict, which they see as counterproductive to the promotion of a positive image. They recognise that English is necessary for modern life, but wish to build a new language ideology whereby:

- bilingualism and linguistic diversity are valued;

- it is not assumed that adopting a new language means abandoning the old; and

- the traditional language is not seen as useless due to its lack of development and prestige.

This echoes the preamble to the European Charter for Regional or Minority Languages, ${ }^{3}$ which, while stressing 'the value of interculturalism and multilingualism', takes into account 'that the protection and encouragement of regional or minority languages should not be to the detriment of the official languages and the need to learn them'.

Cooper (1989: 31) notes that 'some definitions restrict language planning to activities undertaken by governments, government-authorised agencies, or other authoritative bodies' but concludes, 'It would seem, therefore, that to restrict language planning to the work of authoritative institutions is to be too restrictive'. In the campaigning stages of language shift reversal efforts, bottom-up 'planning' is more common than the traditional view takes into account; for example, a large proportion of the case studies in Bradley and Bradley (2002). As noted by Ager in this issue, top-down planners tend to focus on status and corpus planning, whereas bottom-up campaigners focus on image and prestige. All language planning efforts in Guernsey so far have been bottom-up, by private groups and individuals, with little knowledge of linguistics, sociolinguistics or language planning theory, and there has been virtually no support from official bodies.

\section{Language revitalisation groups}

Guernsey is a small island with close-knit social networks, especially among the Guernesiais-speaking community. There are several local groups with an involvement in language revitalisation, but there is a considerable amount of overlap in membership and activities.

- La Gaine du Vouest (The gang from the west), founded 1936, principally a singing group which has released numerous recordings of songs in Guernesiais;

- L'Assembllaïe d'Guernesiais (The Assembly for Guernesiais), founded 1956, principally a forum for speaking Guernesiais;

- Les Ravigotteurs (the Revitalisers), founded about 1995, which promotes second language learning of Guernesiais (all of the above also have a strong social function.)

- La Société Guernesiaise, founded in the late 19th century, is principally a natural history society, but 30-40 years ago it had an active philological section. It continues to publish works in and about Guernesiais;

- The Eisteddfod Committee organises the Guernsey French section of the 
annual Eisteddfod, a general cultural festival which includes everything from cake-making to roller-skating. The Guernsey French section was revived in 1985 and in recent years has expanded from one evening to two; in 2003-2004 seven primary schools and even a few individual children entered the public speaking competitions.

Given the limited number of individuals involved and their other commitments, the indigenous language revitalisation movement has taken the path of collaborating on major events. Lé Coumité d'la Culture Guernesiaise (the Guernsey Cultural Committee) is an umbrella organisation originally formed for a festival in May 2000 involving groups from Guernsey, Jersey and mainland Normandy, which all have more or less mutually intelligible dialects of Norman. The festival has circulated annually between the venues since then and returned to Guernsey in 2003 and 2005, but may outgrow the organisers' capabilities, as all are either retired or have jobs and families.

Many of the activities undertaken, especially those under the auspices of Lé Coumité, have a prestige focus. They often take advantage of other events or commemorations to maximise opportunities to raise awareness of Guernesiais, for example, stressing its historical importance in a Norman feast to commemorate the 800th anniversary of island independence in 2004 using 'the language spoken by King John', or the 200th anniversary of the birth of Victor Hugo, who wrote many of his best known works while in exile in Guernsey and praised the local patois. ${ }^{4}$ The discussion of planning measures below will therefore focus on the prestige elements of each type.

\section{Status planning}

As mentioned above, Guernesiais has no official status; it is not used in any official capacity. A welcoming speech in Guernesiais for a visit by the Queen in 2000 was a significant breakthrough. At no time has the indigenous vernacular ever been considered as an official language or allowed to be used in parliamentary debates, unlike in the modern devolved assemblies of Scotland and Wales in the UK, and there is no provision for translation. One native speaker of Guernesiais who was a member of the island parliament (the States of Deliberation) at the time told me:

Aen caoup dans l's États je dis que si ch'était en guernesiais je pourrais mé m'expressaïbian mus [laugh] -i riyaient [Once in the States I said that if it were in Guernsey French I would be able to express myself much better - they laughed].

There is no overt official language policy in Guernsey, no officially funded bodies with a mandate for language planning, and no publicly funded language officer (as there is in Jersey and the Isle of Man, islands with similar political and sociolinguistic situations). Guernsey is a member of the British-Irish Council, which was created under the Agreement reached in the Multi-Party Negotiations in Belfast in 1998 'to promote positive, practical relationships among its Members, which are the British and Irish Governments, the devolved administrations of Northern Ireland, Scotland and Wales, and Jersey, Guernsey and the Isle of Man' (British-Irish Council, 2004). The other members see maintaining 
regional identity as increasingly important in the era of globalisation, with regional languages a key element. As the only member not to have recognised its indigenous language, Guernsey has come under strong pressure to initiate an official language policy to support Guernesiais. The Government has been put in the position of having to be seen to do more than it is actually doing, to 'project the desired external image' (Ager, 1996: 26); in this context some funding has been offered to groups who can provide budgeted proposals. In anticipation of imminent recognition and funding, a committee including all interested groups has been set up to promote Guernesiais culture across the community as a whole, which proponents hope will become an officially funded commission with a full-time executive and two or three part-time workers. Collaboration with France is also being developed, with Norman French increasingly seen as a common area of cultural heritage. However, campaigning for official status is not currently seen as a priority by all campaigners. Reasons for this include an aversion to bureaucracy, a valuing of independence in policy making, and an unwillingness to cost or devalue voluntary efforts.

The lack of official status affects the visibility of Guernesiais. The lack of signage, that is, written Guernesiais, in the environment has been identified by $L a$ Société Guernesiaise as a priority for increasing its status and hence its prestige. There is only one street sign overtly in Guernesiais: Bian venue à tous (Welcome all) outside the tourist board office (also in several other languages). The tourist board is the only official body to have funded language-related activities. This can be seen as indicative of the increased prestige of Guernesiais, as, unlike in the 1950s and 1960s, it is now seen as an asset rather than as something to be ashamed of.

The majority of place names are still in Guernesiais (Coates, 1991; De Garis, 1976; Howlett, 1983). They tend to be written in French, although Guernesiais speakers usually pronounce them the Guernsey way. For example: Beaucamps

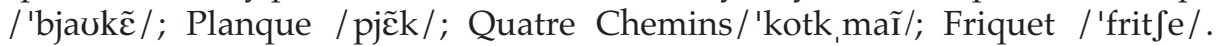
However, knowledge of the Guernesiais pronunciations of these place-names is declining rapidly, and Beaucamps, for example, which is the name of a secondary school, is often called / bovkæmps /. The increased mispronunciation of local place-names due to the lack of familiarity with both French and Guernesiais is a frequent topic of letters to the media. ${ }^{6}$

A sign commonly seen is Ces premises sont terre à l'amende (see Figure 2), which appears at first glance to be in French but which makes very little sense in modern Standard French ('these assertions are land at fine'). The illocutionary meaning is 'no parking'. This is not really Guernesiais but legal French, heavily influenced by Norman, which was used in the UK until at least the 15th century. Guernsey lawyers (known as advocates) still have to spend six months at Caen University in mainland Normandy to familiarise themselves with Norman law, although legal terminology is gradually switching to English.

In the 1950s there were Guinness advertisements in Guernesiais: A-tu-y ta Guinness onier? ('Have you had your Guinness today?'); Guinness est bonne pour te ('Guinness is good for you'). However, the marketing rationale for these declined with the speaker base. Nevertheless, a new hypermarket owned by a Jersey company, which also owns numerous smaller shops in the islands, has signboards with types of produce in Guernesiais (see Figure 3), and also some food 


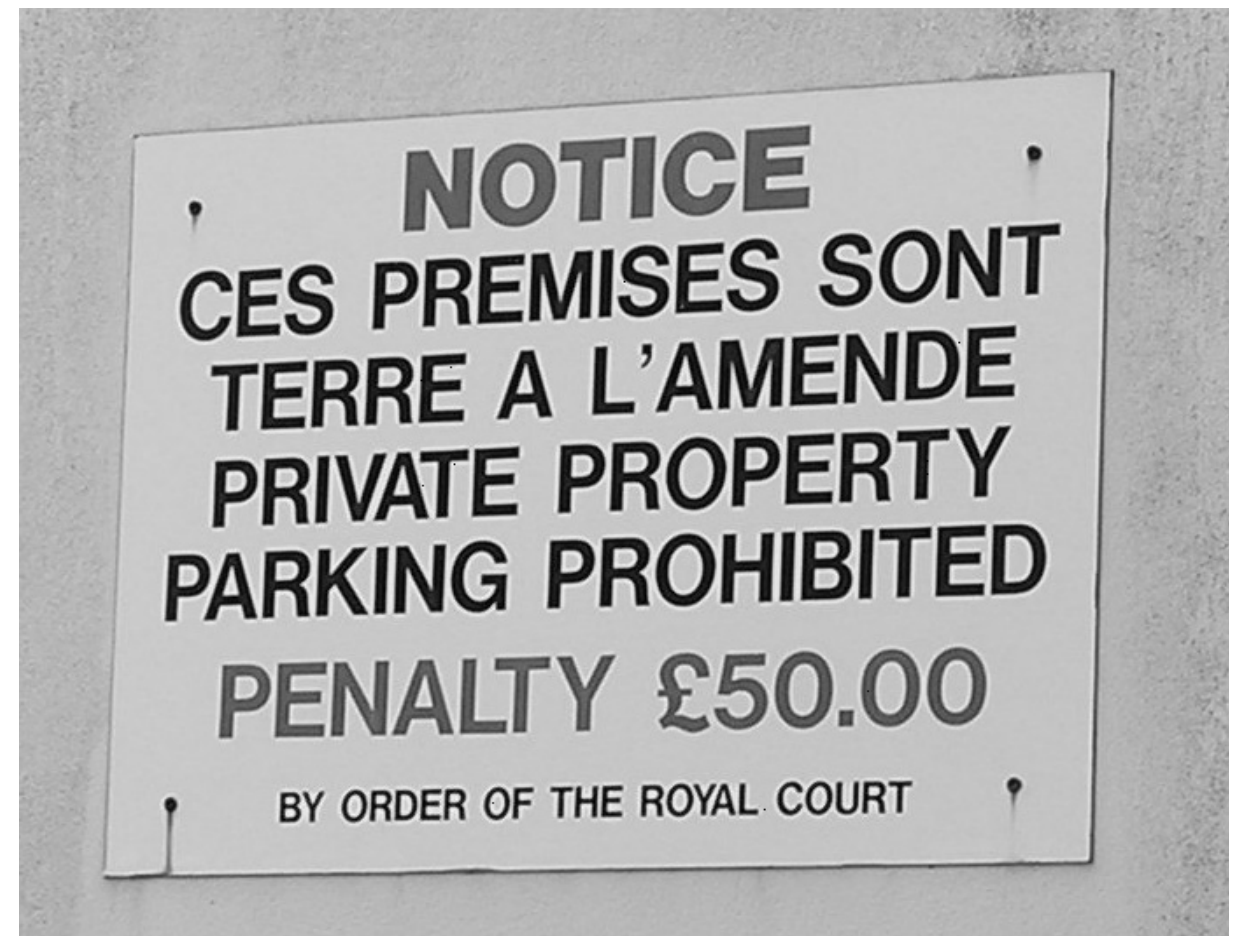

Figure 2 No parking

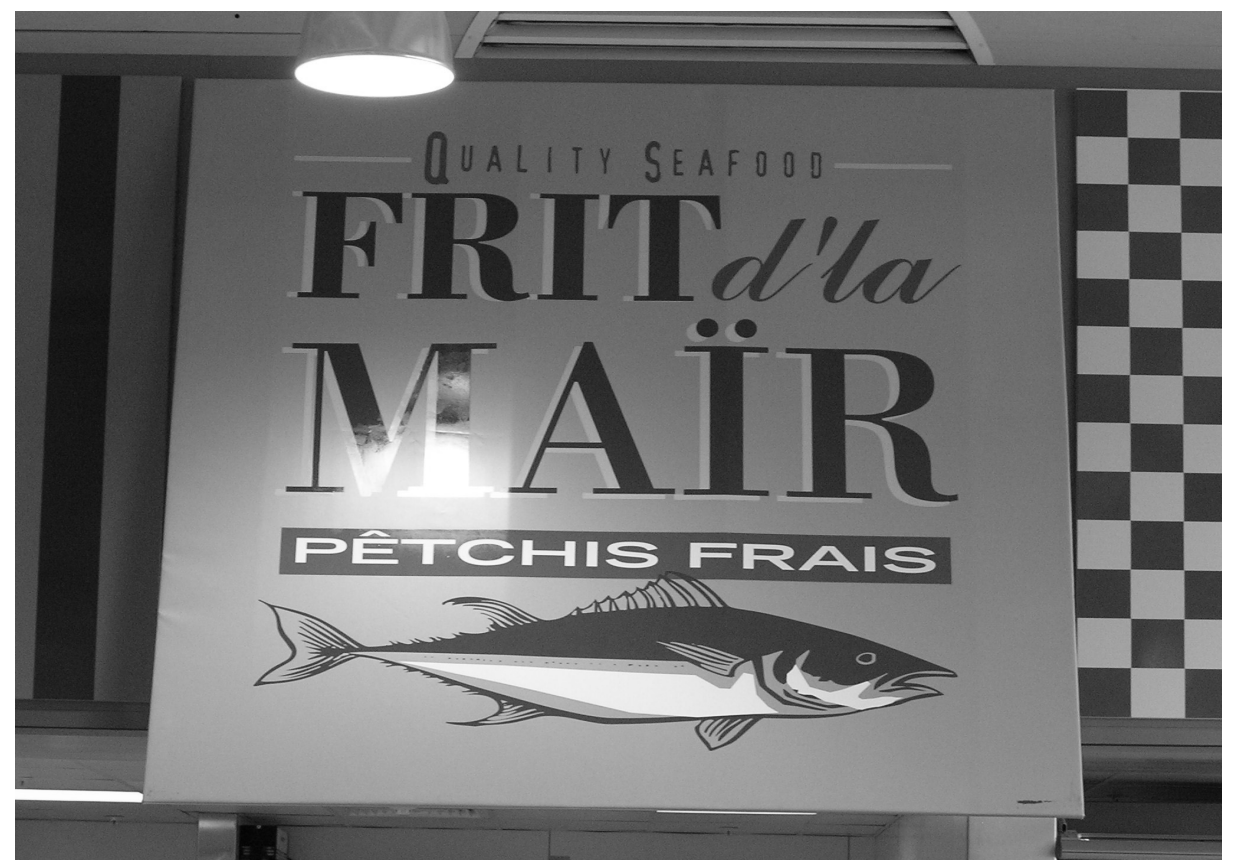

Figure 3 Sign in Guernesiais in a hypermarket 
packets labelled in Guernesiais. The fact that the company signals local identity through the indigenous vernacular as a marketing ploy (presumably to distinguish itself from UK-owned rivals) indicates that it must see this as advantageous.

As will be seen in other areas of language planning, public opinion and private initiatives are thus ahead of official policy. Another example of this is the growing fashion to have house names in Guernesiais (outside the main towns houses do not have numbers); Guernesiais speakers are often asked to suggest names.

Languages which are clearly differentiated from neighbouring languages are termed Abstandsprachen (Kloss, 1967). Others, which have established their identity by emphasising features which distinguish them from related languages, are termed Ausbausprachen. In both categories, the claims of languages to be established in their own right are often furthered by their use as a symbol of national identity in struggles for political independence. French, as the more powerful partner in the pre-20th century diglossic relationship in Guernsey, was the Dachsprache in Kloss's terms, literally 'roof language', sometimes called 'overarching language' in English (Muljačič, 1989). According to Kloss (1952), it should in theory be easier for a language variety to develop into an Ausbausprache if its speakers are politically independent of the overarching variety. As Guernsey is politically separate from France, this should, in theory, allow Guernesiais to develop into a language in its own right. Adler (1977: 99) and Fishman (1991) see political autonomy or self-determination as one of the keys to safeguarding a language's vitality. However, in Guernsey this has not been the case. The island has been politically autonomous since 1204 , but the indigenous language is now highly endangered. It could even be possible that the language has lost prestige due to the lack of need for it as a symbol of independence.

\section{Corpus planning}

As mentioned above, Guernesiais contains very few terms for modern items. Lexical modernisation is not felt to be a priority by campaigners, as the language fulfils a mainly phatic role. This can lead to borrowing from English and lexical erosion in Guernesiais, which some speakers view as problematic, although others cite the influence of Norman on English and view borrowing from English as the return of a long-term loan, pointing out that what many people see as Anglicisms are in fact old Norman terms, e.g. shop, curtains, coat (Gallienne, 2004). While this stresses the former prestige of Guernesiais / Norman, it may be at the expense of its current prestige, as some Anglophones perceive Guernesiais as a random mixture of French and English and use this as an excuse to denigrate it as 'not a proper language'.

There is a certain amount of avoidance of the issue of standardisation among language campaigners, in order to avoid conflicts of opinion. There is no accepted standard spelling, and no single prestige regional variety. There is a high degree of regional variation (a common feature of non-standardised languages), even in such a small island. Relatively few Guernesiais speakers feel comfortable writing it: due to the lack of official recognition, there has never been any literacy training. A sizeable proportion of both speakers and non-speakers 
maintain that it is not a written language. Nevertheless, there is a considerable corpus of literature in Guernesiais, both published (especially 19th century poems by George Métivier, the national poet (Girard, 1980) and his friend Denys Corbet) and unpublished.

However, there have been several dictionaries of Guernesiais compiled, which is one measure of how a language establishes Ausbau and raises its prestige. Métivier compiled the first dictionary in 1870, and contemporary writers praised him for having 'placé le guernesiais au nombre des idiomes reconnus et vivants' ('placed Guernesiais among the ranks of recognised and living tongues') (Boland, 1885: 68). However, his dictionary contains more French than presentday speakers find acceptable (or intelligible). Métivier (1866) referred to French as 'the language of civilisation' and may well have been tempted to 'civilise' Guernesiais by importing French elements.

The most widely used dictionary was compiled in the 1960s by a committee of native speakers from L'Assembllaie d'Guernesiais (De Garis, 1967, revised 1982). Although it is widely respected and represents a huge achievement, the compilers had no linguistic or lexicographical training, and it is not fully consistent. The majority of my respondents who write in Guernesiais claim to use its spelling and some even go and see the editor, Marie de Garis, to ask her to check pieces which are for public consumption (as happened while I was visiting her). This shows an overt awareness of the need for a common spelling, if not a standard; however, an examination of recent writing in Guernesiais shows that in practice writers often ignore the dictionary (Sallabank, 2002). There is anecdotal evidence that, in the absence of literacy training in Guernesiais, speakers who are not aware of its structure (or of Standard French spelling and grammar) find themselves unable to relate the written form to the spoken one.

\section{Language in education}

There is considerable debate in language revitalisation movements worldwide about the role of schools (e.g. Hornberger \& King, 1996). It tends to be a key aim of campaigners, although the received wisdom among researchers is that of Fishman (1991): promoting the speaking of a language in the home is the most effective way of saving it; promoting its use outside the home, such as in schools, can wait. It is also by no means certain that children who only learn a language at school speak it outside, and even less certain that they will raise children speaking it, especially as the kind of language they learn at school is not the kind used in childcare, although Cooper (1989: 13) notes that 'what led to the use of Hebrew at home was its prior promotion as the language of instruction at school'. This was also the case with English in Guernsey: many of my informants stated that a major reason for stopping speaking Guernesiais in the home was that it was not approved of in school. The low prestige of Guernesiais was reinforced by the education system, which explains the key symbolic role of acceptance in schools in increasing its status, prestige, and perceived utility.

Since September 2003 a pilot project has been running optional extracurricular classes once a week in three Guernsey schools with children aged 6-7. One reason for teaching this age group is the lack of an agreed orthographic standard and 'modern' lexis which would be needed for teaching more challenging 
content through Guernesiais. The current scheme was initiated by a member of the island parliament, Jonathan Le Tocq, but it is run on an entirely voluntary basis, with no government finance or prepared materials, and is taught by members of Lé Coumité, Les Ravigotteurs, and the Eisteddfod committee (two of whom are retired French teachers). The lessons are very popular and in one school I observed, there were more parents than children present. Mainstream teachers also attend, and practise with the children between lessons. There is particular interest among parents of British origin, which is significant given that a third of the current population of Guernsey was born outside the island.

It is obvious that with less than an hour a week of input, the pupils are not going to become fluent speakers quickly. The main benefits of the scheme are symbolic: as a foot in the door to official acceptance, and to value local identity, which is the factor cited in media coverage: " $\mathrm{I}$ 'm under no illusion that it'll become our business language, but it is a vital part of our culture", he [Le Tocq] said' (Baudains, 2004).

The problem with a voluntary scheme is that, as with the inter-island festival mentioned earlier, it may not be sustainable. There are more schools wanting to take part than the volunteer teachers can cope with, and there are not enough teachers or resources to both continue with the children who have done one year, and introduce Guernesiais to a new set of children. But disappointing either group might risk losing some of the goodwill that has been gained.

One government initiative which may have a positive effect on indigenous language maintenance (but which is still at a rudimentary stage) is the possibility of including Guernesiais in the new school Citizenship curriculum. Although there is considerable pride in Guernsey's independence and constitution among both the public and politicians, little local culture or history is taught in schools. By and large, Guernsey follows the British National Curriculum, although it does not have to. The Education Department has been criticised for this lack of autonomy:

Many teachers come to Guernsey on short-term contracts, they bring with them their culture and experience but not knowledge of the island. Nothing of island history or culture is taught in its schools. The English National Curriculum is followed. Younger Guernsey people are denied knowledge not only of the Christian faith and the French language, but also of their own cultural heritage. (Le Poidevin, 2004: 16)

However, in the area of Citizenship, the island authorities have realised that the British curriculum bears no relevance to local needs, and have proposed a syllabus along the lines of 'Local Heritage', which may include Guernesiais, probably focusing on raising awareness.

\section{Prestige and image planning}

As mentioned earlier, Guernesiais is a very low-status variety, often seen as a patois or corrupt French; indeed, Standard French is still known as 'Good French'. Current language planning measures focus on promoting acceptance of Guernesiais as a legitimate mode of expression, and providing opportunities for speakers and learners to use it. For example, as mentioned above, festivals are one of 
the few forums for speaking and hearing Guernesiais publicly, both among the audience and by announcers. They are attended mainly by Guernesiais speakers (and provide an important social function for isolated speakers), but also by tourists, friends and relatives of performers, and other interested members of the public. Festivals increase the visibility of Guernesiais and allow speakers to express pride in it, for example through media coverage, which is important for both awareness-raising and prestige.

The only TV or radio provision in Guernesiais is five minutes a week of radio news at 8.35 am on Saturdays. Given this timing, remarkably $41 \%$ of interviewees who answered this question said they always listen, and $53 \%$ more listen sometimes. Interestingly, $26 \%$ of non-speaker questionnaire respondents reported sometimes listening, and 3\% always: four more in total than the 11 non-speaker respondents who understand some Guernesiais.

From 2001 to 2003 there was a short column in Guernesiais in a free weekly newspaper (with an English translation). Articles were contributed by the Ravigotteurs group, and provided a valuable showcase for demonstrating that non-traditional topics could be addressed in Guernesiais (e.g. the bombing of Afghanistan, or new roads), but the project was eventually abandoned due to the difficulty of obtaining regular copy, and in many cases translating it. A more recent initiative takes a different approach: the major daily paper in Guernsey has agreed to run a regular short feature giving Guernesiais vocabulary with pictures and pronunciation tips, plus a dire du jour (saying of the day). This is seen by the initiators as less challenging and more reader-friendly than longer articles, and ties in with language-in-education initiatives. The stated aim is to raise the profile of Guernesiais and attract people not originally interested in language issues (Jonathan Le Tocq, p.c.).

Some minority languages, such as Welsh or Gaelic, had their prestige as literary languages enhanced by the translation of the Bible, and numerous other languages have first been given an orthography by missionaries. However, the Bible has never been translated into Guernesiais; after the Protestant Reformation in the 16th century, a French Bible and Prayer Book were used once the Anglican Church realised that nobody understood the English ones. In the first few interviews I conducted, one of the questions I asked interviewees was which language they talked to God in, following the example of Gal (1979), on the assumption that this would be the language they felt most emotionally close to. However, the reaction of interviewees to this question was quite negative, and I soon learnt that Guernesiais was not considered of high enough prestige for talking to God. Nevertheless, attitudes are changing: l'Assembllaie d'Guernesiais holds annual ecumenical church services in Guernesiais, and in 2001 a new minister at a Methodist church in Torteval, the westernmost part of Guernsey where Guernesiais now has most ethnolinguistic vitality, was welcomed with a hymn sung in Guernesiais.

Negative attitudes towards minority languages are well documented in the literature (e.g. Baker, 1992; Dorian, 1981; Kuter, 1989; Williamson, 1991 inter alia) and both contribute to and are reinforced by low prestige, a vicious circle which leads to an ideology of deficit and promotes language shift. It is not uncommon for this ideology to be internalised by the speakers themselves: Labov (1966: 489) claimed that 'the term "linguistic self-hatred" may not be too extreme'. Spence 
(1993: 4) notes of Jersey: 'The fact that many of those who habitually spoke Jèrriais themselves regarded it as a "patois" is certainly a significant factor in its decline, in so far as it made them less committed to the survival of the vernacular, and influenced the attitude of their children.'

As with many other minority vernaculars, Guernesiais has been perceived as an impediment to social advancement. Many people I have interviewed, especially Anglophones, view the local indigenous vernacular as 'useless':

I think it would be more useful to teach good French. (Catholic priest, mid-60s)

I think it would be more useful to teach a modern European language such as French or German. (Dentist, male, early 40s)

If children are going to learn another language at school they should learn proper French or German or Spanish, or even an Eastern language - a language that's widely used. (Retired teacher, female, early 70s)

However, speakers now demonstrate increased confidence and pride in Guernesiais:

I think that was the thing - that's how we started to lose it after the war er it wasn't the in thing - to speak Guernsey French and that is right that in certain company you didn't speak it - because it made you feel a bit inferior but now it's the other way round - you don't feel at all inferior if you know it, it's completely the opposite you know? (Retired politician, male, 70s)

I was put down at school for being from the country and didn't admit to speaking Guernsey French ... J'oimerais bian que tout ma fomille [pâle] pasque quënd j'étais p'tite j'étais embarrassaï dé lé pâlaï mais ... aucht'haeure je sis aen amas fière que je peur lé pâlaï [ . . . I'd like all my family [to speak] because when I was little I was embarrassed to speak it but ... now I'm very happy that I can speak it']. (Office worker, female, 50s)

Although over half of the school pupils aged 11-18 interviewed at four secondary schools reported having little interest in Guernesiais, a small but significant proportion independently expressed interest in learning it as 'a secret language of our own'. This kind of covert prestige (Dauenhauer \& Dauenhauer, 1998) appeals to affect rather than status, and may offer a way for language planners to sell traditional language and culture to young people, as they place little value on it otherwise.

\section{Prospects for Revitalisation}

Comments from research respondents provide useful insights into the perceived success of language planning. There is a new realisation that Guernesiais really might disappear; until now it has been taken for granted as part of the island's background, and ignored. Hence the desire of groups to raise its profile in the community.

For language maintenance and revitalisation measures to gain the support of gate-keeping and funding authorities, they need to be accepted by the majority community, who by definition do not speak the minority language. Some 
non-Guernesiais-speaking respondents are overtly hostile to revitalisation: 'No point in trying to revive - waste of time - Latin far more valuable'; 'Communication between groups should be made easier rather than reintroducing an incomprehensible patois'; 'The only people who want to save the language are intellectuals'.

However, these respondents were in a minority, and my surveys revealed substantial though passive support for language revitalisation among nonspeakers: e.g. 'It would be a tragedy if it were to die out'; 'I would welcome its return via schools - wish I had had the opportunity'. Many were supportive but pessimistic, e.g. 'Not enough middle-aged people, too much of a gap'; 'Brave attempts by Ravigotteurs to keep language alive, but too far gone for long-term revival'. Considerable prestige and image planning will be needed to overcome such pessimism.

Bottom-up efforts may be effective in improving a language's image: Cooper (1989: 161) contrasts the relative success of language planning for the revitalisation of Māori and Irish, commenting that in New Zealand 'the initiative for the revitalisation program has come from the Maoris themselves', whereas in Ireland 'the government promoters of maintenance made no serious attempt to promote the enthusiasm of people of the Gaeltacht themselves. The initiative came from outside'. Nevertheless, Spolsky (2004: 198 and p.c.), also commenting on Māori revitalisation, sees eventual government recognition and support as essential for success. Certainly this would provide more time, funds and resources than private groups and individuals currently have at their disposal. Language revitalisation in Guernsey still has a long way to go before it can claim the (relative) success of Welsh or Māori, and it is likely that the current older generation will be the last fluent native speakers.

\section{Conclusion}

It could easily be said that current language planning efforts in Guernsey are too little, too late. But as Dorian (1987) points out, even unsuccessful attempts raise awareness and prestige of a language. This is a necessary prerequisite to language planning in Guernsey as some residents, especially those of non-island origin or in the more Anglicised areas, are not even aware that it has an indigenous language: one informant who is a civil servant reported being asked by a British colleague what language she had been speaking on the phone to a Guernesiais-speaking colleague. I also found very low levels of awareness at a school in the second largest town (St Sampson), which was one of the earliest places to be Anglicised.

It can be argued that all the current efforts involve a measure of prestige and image planning, either overtly or implicitly (although most grass-roots campaigners are not aware of the concepts). It can also be argued that this is a prerequisite for the acceptance and success of other measures, as any publicly funded measures would require the support of the Anglophone majority. However, prestige planning is not enough on its own to revive ethnolinguistic vitality, including intergeneration transmission. Some speakers whose performance in festivals is high in terms of accent and accuracy, or who teach Guernesiais in the schools project, lack the confidence to speak Guernesiais in their everyday life, or 
to transmit it to their own children. For ethnolinguistic vitality to be revived, prestige and image planning would have to reach a critical mass whereby the climate was ready for more substantive measures such as effective language teaching (e.g. immersion), full documentation, and community measures such as childcare classes including Guernesiais and a master-apprentice programme (Hinton, 1997) to link isolated speakers with learners. But Thieberger (2002) argues that token maintenance may be adequate for image and identity purposes: 'language revival need not be an "all or nothing" venture'. The planning aspect of language revitalisation in Guernsey has not yet reached the stage of discussing the end goal; consensus is seen as essential for effective campaigning, so that as with standardisation, debating such issues may be seen as potentially divisive.

I have noticed attitudes changing perceptibly over the five years of my research so far: the prestige of Guernesiais is growing and it is generally now seen as a valuable part of island heritage. Very few people, and no public figures, are now prepared to make on-the-record statements against indigenous language revitalisation. Although there have so far been few official initiatives, the climate seems to be ripe for public support of private efforts. Nevertheless, there is still little sense of urgency, and prestige and image planning remains at the 'drip-feed' level. Without larger-scale measures in all areas of language planning, it is likely that the current efforts will be too little, too late.

\section{Acknowledgements}

The researcher is grateful to the UK Economic and Social Research Council for funding this ressearch.

\section{Correspondence}

Any correspondence should be directed to Julia Sallabank, Department of Linguistics and English Language, Lancaster University, LA1 4YT, United Kingdom (julia@torteval.co.uk).

\section{Notes}

1. Martel (1966:51) wrote: 'We have not used the pejorative word "patois" for our dictionary. According to the Larousse dictionary, "patois" means "l'idiome populaire propre à une province et surtout un langage bizarre et incorrect"' ["the popular variety belonging to a province and above all bizarre and incorrect language $\mathrm{e}^{\prime \prime}$. Many British and some Guernsey people also associate the word patois with 'creole' due to its association with Jamaican patois.

2. The researcher's mother is from Guernsey and the researcher spent most summers there when a child. Although the family did not speak Guernesiais, there must have been some passive exposure as it seems very familiar when 'relearning' it. As there are no published materials available for learning Guernesiais and the researcher could not spend enough time in Guernsey to attend evening classes, she learnt to speak Guernesiais by talking to speakers, using her knowledge of French as support. The researcher also had the experience, common to many Guernesiais speakers, of finding French very easy at school.

3. The Charter has, of course, no force in Guernsey as it is not a full member of the European Union, and most activists are not aware of it.

4. It is also claimed, apocryphally, that Hugo introduced a Guernesiais term into Standard French: pieuvre 'octopus'. 
5. The pronunciation of beau in the English word 'beautiful' and the place-name 'Beaulieu' illustrates the amount of influence from Norman on English.

6. Radio announcers on short-term contracts from the UK come in for special criticism.

\section{References}

Adler, M. (1977) Welsh and the Other Dying Languages of Europe: A Sociolinguistic Study. Hamburg: Buske.

Ager, D.E. (1996) Language Policy in Britain and France: The Processes of Policy. Clevedon: Multilingual Matters.

Ager, D.E. (2005) Prestige and image planning. Current Issues in Language Planning (this issue).

Baker, C. (1992) Attitudes and Language. Clevedon: Multilingual Matters.

Baudains, N. (2004) Pilot scheme will teach our language. Guernsey Press (2 January), 5.

Boland, H. (1885) Les institutions de langue française à Guernesey [French language institutions in Guernsey]. Revue Internationale 8, 66-85 and 190-212.

Bradley, D. and Bradley, M. (eds) (2002) Language Endangerment and Language Maintenance: An Active Approach. London: RoutledgeCurzon.

British-Irish Council (2004) Work of the British-Irish Council: Minority and lesser-used languages. On WWW at http://www.britishirishcouncil.org/work/language.asp. Accessed 24.09.04.

Bunting, M. (1995) The Model Occupation. London: HarperCollins.

Coates, R. (1991) The Ancient and Modern Names of the Channel Islands: A Linguistic History. Mediaeval Studies 6. Stamford: Paul Watkins.

Cooper, R. (1989) Language Planning and Social Change. Cambridge: Cambridge University Press.

Dauenhauer, N.M. and Dauenhauer, R. (1998) Technical, emotional, and ideological issues in reversing language shift: Examples from Southeast Alaska. In L.A. Grenoble and L.J. Whaley (eds) Endangered Languages: Language Loss and Community Response (pp. 57-98). Cambridge: Cambridge University Press.

De Garis, M. (ed.) (1967, revised 1982) Dictiounnaire Angllais-Guernesiais [EnglishGuernesiais Dictionary]. Chichester: Phillimore.

De Garis, M. (1973) Philological report. Transactions of La Société Guernesiaise 19, 260-61.

De Garis, M. (1976) Glossary of Guernsey Place-Names. St Peter Port, Guernsey: Société Guernesiaise.

Dorian, N.C. (1981) Language Death: The Life Cycle of a Scottish Gaelic Dialect. Philadelphia: University of Pennsylvania Press.

Dorian, N.C. (1987) The value of maintenance efforts which are unlikely to succeed. International Journal of the Sociology of Language 68, 57-67.

Fishman, J.A. (ed.) (1991) Reversing Language Shift: Theoretical and Empirical Foundations of Assistance to Threatened Languages. Clevedon: Multilingual Matters.

Fishman, J.A. (ed.) (2001) Can Threatened Languages be Saved? Reversing Language Shift, Revisited: A 21st Century Perspective. Clevedon: Multilingual Matters.

Gal, S. (1979) Language Shift: Social Determinants of Linguistic Change in Bilingual Austria. New York: Academic Press.

Gallienne, W.T. (2004) The importance of our language. Review of the Guernsey Society 60 (2), 24-6.

Gardner, N. (1993) Goodwill, Language Planning and Language Policies. Carmarthen: Joint Working Party on Bilingualism in Dyfed.

Girard, P. (1980) George Métivier, Guernsey's national poet. Report and Transactions of La Société Guernesiaise 20, 617-23.

Haarmann, H. (1984) Sprachplanung und Prestigeplanung [Language planning and prestige planning]. Europa Ethnica 41 (2), 81-9.

Haarmann, H. (1990) Language planning in the light of a general theory of language: A methodological framework. International Journal of the Sociology of Language 86, 103-26.

Hinton, L. (1997) Survival of endangered languages: The Californian Master-Apprentice program. International Journal of the Sociology of Language 123, 177-91. 
Hornberger, N.H. and King, K. (1996) Language revitalization in the Andes: Can the schools reverse language shift? Journal of Multilingual and Multicultural Development 17, 427-41.

Howlett, C.J. (1983) Guernsey Street and Road Names: A History of the Parishes and their Folklore. Guernsey: Howlett.

Johnstone, P. (1994) A Short History of Guernsey (4th edn). Guernsey: Guernsey Press.

Kaplan, R.B. and Baldauf, Jr, R.B. (2003) Language and Language-in-Education Planning in the Pacific Basin. Dordrecht: Kluwer.

Kloss, H. (1952) Die Entwicklung Neuer Germanischen Kultursprachen von 1800-1950 [The Development of New Germanic Languages of Culture from 1800-1950]. Munich: Pohl.

Kloss, H. (1967) 'Abstand languages' and 'Ausbau languages'. Anthropological Linguistics 9, 29-71.

Kuter, L. (1989) Breton vs. French: Language and the opposition of political, economic, social, and cultural values. In N.C. Dorian (ed.) Investigating Obsolescence: Studies in Language Contraction and Death (pp. 75-89). Cambridge: Cambridge University Press.

Labov, W. (1966) The effect of social mobility on linguistic behavior. Social Inquiry 36, 186-203.

Le Poidevin, N. (2004) Whither Guernsey revisited. Review of the Guernsey Society 60 (2), 15-18.

Marquis, J. (1997) La situâtiaon d'la langue en Guernesi depis la Réformâtiaon au jour $\mathrm{d}^{\prime}$ ogniet [The language situation in Guernsey from the Reformation to the present day]. Le Viquet 117, 6-16.

Marr, J. (2001) The History of Guernsey: The Bailiwick's Story. Guernsey: Guernsey Press.

Martel, E. (1966) Some thoughts on the compiling of 'Le Dictiounnaire AngllaisGuernesiais'. Transactions of la Société Guernesiaise 18, 49-51.

Métivier, G. (1866) Fantaisie Guernesiaise: Dans le Langage du Pays, la Langue de la Civilisation, et Celle du Commerce [Guernsey Fantasy: In the Speech of the Country, the Language of Civilisation, and that of Commerce]. Guernsey: Thomas-Mauger Bichard.

Métivier, G. (1870) Dictionnaire Franco-Normand, ou Recueil des Mots Particuliers au Dialecte de Guernesey: Faisant voir les Relations Romaines, Celtiques et Tudesques [Franco-Norman Dictionary, or List of Words Particular to the Dialect of Guernsey: Demonstrating the Romance, Celtic and Teutonic links]. Guernsey: Thomas-Mauger Bichard.

Milroy, J. (1984) The history of English in the British Isles. In P. Trudgill (ed.) Language in the British Isles (pp. 5-31). Cambridge: Cambridge University Press.

Milroy, L. (1987) Language and Social Networks (2nd edn). Oxford: Blackwell.

Muljačič, Z. (1989) Über den Begriff Dachsprache [On the concept of Dachsprache]. In U. Ammon (ed.) Status and Function of Languages and Language Varieties (pp. 256-77). Berlin: Walter de Gruyter.

Sallabank, J. (2002) Writing in an unwritten language: The case of Guernsey French. Reading University Working Papers in Linguistics 6, 217-44.

Scovel, T. (1998) Psycholinguistics. Oxford: Oxford University Press.

Spence, N.C.W. (1993) A Brief History of Jèrriais. Jersey: Le Don Balleine.

Spolsky, B. (2004) Language Policy. Cambridge: Cambridge University Press.

Thieberger, N. (2002) Extinction in whose terms? Which parts of a language constitute a target for language maintenance programmes? In D. Bradley and M. Bradley (eds) Language Endangerment and Language Maintenance: An Active Approach (pp. 310-28). London: RoutledgeCurzon.

Thomason, S.G. and Kaufman, T. (1988) Language Contact, Creolization, and Genetic Linguistics. Berkeley: University of California Press.

Watson, S. (1989) Scottish and Irish Gaelic: The giant's bed-fellows. In N. Dorian (ed.) Investigating Obsolescence: Studies in Language Contraction and Death (pp. 41-59). Cambridge: Cambridge University Press.

Williams, G. (2000) Language Planning and Language Use: Welsh in a Global Age. Cardiff: University of Wales Press.

Williamson, R.C. (1991) Minority Languages and Bilingualism: Case Studies in Maintenance and Shift. Norwood, NJ: Ablex.

Youngman, M.B. (1978) Designing and Analysing Questionnaires. Rediguide 12. University of Nottingham School of Education. 


\section{The Author}

Julia Sallabank is a doctoral student at Lancaster University, UK, doing research on the sociolinguistics of Guernsey Norman French. She previously gained an MA in Teaching English to Speakers of Other Languages from the Institute of Education, University of London. For the past 14 years she has also been working as an editor at Oxford University Press. Her research interests include language shift, French sociolinguistics, and child foreign language learning. She has presented papers at several international conferences, including the European Science Foundation Network on Minority Languages, the German Linguistics Association, the British Association for Applied Linguistics, and AILA. 